\title{
USVOJENOST ZELENOG MARKETINGA MEĐU MLADIM POTROŠAČIMA U HRVATSKOJ
}

\author{
Davor Širola \\ Dr. sc., v. pred., Veleučilište u Rijeci, Vukovarska 58, 51000 Rijeka, Hrvatska; e-mail: davor.sirola@veleri.hr
}

\section{Anabela Rosandić}

Struč. spec. oec; e-mail: anabelarosandic@gmail.com

\begin{abstract}
SAŽETAK
Posljednjih godina globalne promjene koje se događaju u okolini i u društvu dovode do sve veće svijesti pojedinaca o potrebi očuvanja okoliša, a time i očuvanja vlastite kvalitete života. Povećanjem ekološke svijesti dolazi do stvaranja novog segmenta potrošača, tzv. zelenih potrošača, koji se zalažu za proizvode koji nemaju negativne utjecaje na okolinu u kojoj živimo. Nastankom zelenih potrošača stvaraju se i oblikuju aktivnosti koje se mogu nazvati zelenim marketingom, što podrazumijeva proizvode koji uzimaju u obzir njihov utjecaj na okoliš i društvo. Empirijsko istraživanje u sklopu rada provedeno je primjenom teorije planiranog ponašanja s ciljem utvrđivanja varijabli koje predstavljaju prediktore spremnosti na kupnju i uporabu ekoloških proizvoda i usluga prvenstveno u mlađe populacije. Rezultati istraživanja upućuju da su stavovi zabrinutosti za okoliš, znanje o tematici ekologije i svijest o važnosti očuvanja okoliša statistički značajno povezani s namjerama kupnje i uporabe ekoloških proizvoda i usluga, dok subjektivne norme nemaju statistički značajnu povezanost. Veća zabrinutost za okoliš uturđena je kod žena te kod starijeg dijela ispitanika.
\end{abstract}

Ključne riječi: zeleni marketing, okoliš, teorija planiranog ponašanja

\section{UVOD}

Posljednjih desetljeća zabrinutost za okoliš postala je ne samo važno javno pitanje, već jedna od ključnih tema akademskih istraživanja. Takva situacija posljedica je vjerojatno nepovratnih promjena klime, kao i niza okolišnih izazova (Kotler, 2011:132): slabljenje ozonskog omotača, degradacija zemlje, pojačano zagađenje zraka i vode, smanjivanje dostupnosti svježe pitke vode te rastuća potrošnja fizičkih i prirodnih resursa. Ovi izazovi potakli su jačanje svijesti o važnosti čovjekova okoliša u SAD-u i zapadnoj Europi još od 1970-ih, a na znanstvenoj razini razvoj novog područja marketinga poznatog pod nazivima 'zeleni,' 'održivi, 'ekološki' ili 'okolišni' marketing koje se često drže sinonimima (primjerice: Dangelico i Vocalelli, 2017:1264). 
Problem koji se analizira u radu razmatra se sa stanovišta potrošača, posebice mladih potrošača koji će potencijalno najviše osjetiti koristi (ili slabosti) u planiranju i realizaciji gospodarskog razvoja u pogledu održivosti njegova utjecaja na okruženje. Cilj ovog rada je primjenom teorije planiranog ponašanja (Ajzen, 1991) odgovoriti na glavnu hipotezu rada, odnosno utvrditi povezanost pojedinih prediktora namjera kupnje i uporabe ekoloških proizvoda i usluga te utvrditi postoji li dobna diferencijacija u Hrvatskoj u pogledu ekoloških problema. Rad je strukturiran u šest cjelina, i to uvod, pregled literature koji obuhvaća razvoj zelenog marketinga i primjene teorije planiranog ponašanja u tom kontekstu, zatim prikaz metodologije koji uključuje hipoteze rada, rezultate istraživanja te zaključna razmatranja.

\section{PREGLED LITERATURE}

\section{1 Razvoj zelenog marketinga}

Rastuća sklonost životnom stilu koji uključuje svijest o važnosti našeg okoliša traje već više od tri desetljeća. Od začetaka u dalekim 1960-ima, pa do novog milenija, kada taj trend postaje prevladavajući, različiti oblici zabrinutosti za naše prirodno okruženje i resurse rastu. Primjerice, prema istraživanju Eurobarometra iz 2017. godine (European Commision, 2017:4) 94 \% ispitanika Europske unije drži da je zaštita okoliša vrlo važna za njih osobno što je porast od $14 \%$ u odnosu na 2007. godinu. Pritom, barem zasad, povećanu zabrinutost stanovnika Europske unije ne uspijeva umanjiti činjenica da neki pokazatelji održivosti okoliša u EU28 pokazuju pozitivna kretanja.

Ekološke promjene i osviještenost potrošača o utjecaju čovjeka na zagađenje, odnosno očuvanje okoliša, stvorili su segment ekološki odgovornih potrošača, kojima se prilagodila i koncepcija marketinga, tako da su uvrštene ekološke i društvene dimenzije (Tolušić et al., 2014:25). Sam pojam zelenog marketinga prvi je uveo Lazer 1969. godine (Kumar, 2016:137). Kao ilustraciju razvoja definicija zelenog/održivog/ekološkog marketinga od 1970-ih do danas vrijedi istaknuti tri važnije definicije (odabrano prema Dangelico i Vocalelli, 2017:1268, Kotler i Armstrong, 2012:582): „zeleni marketing je holistični proces odgovoran za identifikaciju, predviđanje i zadovoljavanje potreba potrošača i društva na profitabilan i održiv način“ (Peattie, 1995); „marketing proizvoda za koje se smatra da su sigurni za okoliš“" (AMA, 2012); „održivi marketing poziva na društveno i okolišno odgovorne aktivnosti koje susreću potrebe potrošača i poslovnih subjekata, dok istovremeno čuvaju okoliš i osnažuju sposobnost budućih generacija da zadovolje svoje potrebe" (Kotler i Armstrong, 2012).

Razvoj zelenog marketinga može se promatrati kroz tri faze. U 1970-ima zeleni marketing tretiran je kao podskup aktivnosti vrlo uskog fokusa na specifične ekološke probleme, poput zagađenja zraka ili pretjeranog iskorištavanja prirodnih resursa (Dangelico, Vocalelli, 2017:1266). Tek s brzim rastom zelenog konzumerizma, krajem 1980-ih i u 1990-ima, nastupa druga faza, kada zeleni marketing postaje predmetom brojnih istraživanja. Usprkos optimističnim predviđanjima, do polovice 1990-ih zabilježen je zanimljiv paradoks. lako je društvo sve više simpatiziralo za okoliš povoljne proizvode (engl. environmental friendly), zeleni proizvodi postigli su vrlo ograničen uspjeh. Ovakva situacija obično se opisuje kao jaz između stavova i ponašanja; primjerice, $u$ istraživanjima 30 do 50 \% potrošača iskazuje namjere kupnje 
zelenih proizvoda, no tržišni udjel tih proizvoda iznosi manje od 5 \% (primjerice: Carrington et al., 2010; Young et al., 2010, Greenindex, 2012, citirano u Terlau i Hirsch, 2015:160; Tanner i WölfingKast, 2003; Vermeir i Verbeke, 2006, citirano u Joshi i Rahman, 2016:455).

U trećoj fazi (od 2000. godine) zeleni marketing stavlja naglasak na održivost (održivi marketing) i to kroz pokrivanje punih ekoloških troškova proizvodnje i potrošnje, da bi se stvorila održiva ekonomija (Dangelico, Vocalelli, 2017:1266-1267). Nadalje, u trećoj fazi zeleni konzumerizam vodi prema još širem konceptu etičkog konzumerizma, koji podrazumijeva brigu o kršenju ljudskih prava i prava djece koju iskorištavaju u proizvodnji, testiranju proizvoda na životinjama, suzbijanju sindikalnih aktivnosti itd., a stroža vladina regulativa (primjerice, prema zavaravajućim ekoporukama) i utjecaj nevladinih organizacija i medija povećao je kvalitetu zelenih proizvoda (Lee, 2008:575).

\section{2 Dob potrošača i zeleni marketing}

Dob potrošača istraživale su brojne studije. U metaanalizi Wiernik et al., (2013:830-836 i 842) usporedili su rezultate 68 radova s ukupno 220 nezavisnih uzoraka iz 20 država (ukupno 87.988 ispitanika) za različite varijable ekološke održivosti poput: zabrinutosti za okoliš (mladi bi mogli biti zabrinutiji zbog društveno-emotivne selektivnosti, odnosno osjećaja dužeg preostalog životnog vijeka), ekološke svijesti (mladi će vjerojatno tražiti više ciljanih informacija, što će ih potencijalno učiniti ekološki svjesnijima), ekološkog znanja (moguće je da će mladi steći više ekoloških znanja), društvenih normi (stariji će možda biti motiviraniji društvenim normama), stavova prema ekološkom ponašanju (mladi će imati više pozitivne stavove prema ekološkom ponašanju) i proekološke namjere (mladi će imati snažnije ekološke ponašajne namjere). Generalni zaključci metaanalize upućuju na relativno slabu dobnu diferencijaciju rezultata ovih varijabli ( $\rho$ u rasponu od $-0,13$ do 0,22 ).

$\mathrm{U}$ kontekstu istraživanja mladih posebno je zanimljiva skupina tzv. „milenijalaca“ (naziva se i "generacija Y“ ili „echo-boomeri“), koja predstavlja jednu od najbrojnijih i najvažnijih skupina potrošača današnjice. Obično se u tu skupinu ubrajaju osobe rođene između 1979. i 1994. godine (Kotler, Armstrong, 2012:219), koje danas imaju između 24 i 39 godina. U SAD-u (prema US Census 2015) čine najveću dobnu skupinu s oko $25 \%$ udjela, dok u EU28 čine treću najveću skupinu s 17 \% u 2017. godini (https://ec.europa.eu/eurostat), te u Republici Hrvatskoj prema popisu iz 2011. godine drugu najveću skupinu (DZS, 2013:11) s $25 \%$.

Značajan udio milenijalaca u ukupnom broju stanovnika potaknuo je i sve veći broj znanstvenika da svoja istraživanja fokusiraju na mlade potrošače. Primjerice, Naderi i Van Steenburg (2018:281) navode primjere 17 studija provedenih među mladima (između 2008. i 2017.), no kao i u metaanalizi Wiernik et al. (2013), niti ovdje rezultati nisu konzistentni, budući da je utvrđena dobna diferencijacija mladih u odnosu na druge dobne skupine samo prema ekološkom znanju, životnom stilu, društvenim normama, utjecaju roditelja na ekološke stavove i spolu, ali ne i dostupnosti, kvaliteti i višoj cijeni zelenih proizvoda. U pogledu spola, primjerice, Uddin i Khan (2016:93) utvrdili u statistički značajno više ekološke stavove i zelene kupovne navike kod žena (studentica) u odnosu na muškarce (studente) u Indiji. 


\subsection{Modeli istraživanja ponašanja potrošača}

Za analizu ponašanja potrošača korištene su različite teorije i modeli. Za razumijevanje ponašanja mnogi znanstvenici oslonili su se na sociološko-psihološka istraživanja, poput teorije planiranog ponašanja, koju je razvio Ajzen Icek 1991. godine.

Teorija planiranog ponašanja primijenjena je u brojnim studijama u vrlo raznovrsnim poljima i granama. U sklopu bibliografskog pregleda na web-stranici autora teorije Iceka Ajzena, (https:// people.umass.edu/aizen/index.html), navedeno je preko 2.200 radova u kojima je tijekom triju desetljeća (do svibnja 2018. godine) primijenjena teorija planiranog ponašanja. Nadalje, teorija planiranog ponašanja koncipirana je otvoreno za uključivanje dodatnih prediktora, pored osnovnih: stavovi prema ponašanju, subjektivne norme, percipirana kontrola ponašanja i namjere ponašanja. Pored toga, prethodne primjene modela u sklopu teorije planiranog ponašanja $u$ kontekstu ekoloških istraživanja pokazale su relativno konzistentne rezultate. Tako su Joshi i Rahman (2016:463) najvažnijim prediktorima kupnje zelenih proizvoda kod mladih utvrdili: društveni utjecaj (norme), stavove prema kupnji zelenih proizvoda, percipiranu razinu ekološkog znanja, sudjelovanje u recikliranju i ekološke etikete (rezultati ß koeficijenta od 0,33 do 0,18, pri $p<0,0001)$. Slične rangove važnosti ovih prediktora kupnje zelenih proizvoda utvrdio je i Lee (2008:579).

Kod domaćih autora teorija planiranog ponašanja solidno je prisutna $u$ istraživanjima i to $u$ različitim poljima i granama (sociologija, medicina, poduzetništvo, marketing i dr.). Među 50-ak pronađenih znanstvenih radova hrvatskih autora, 20-ak se bavi analizom ponašanja koja su barem dijelom povezana s temama ekologije i zelenog/održivog marketinga (primjerice: Begić, 2015.; Ham, 2009., 2012., 2013., 2015., 2016., 2018.; Krupka i Kelečić, 2012.; Mihić, 2008.; Martić Kuran i Mihić, 2014.; Nefat, 2013., 2015.; Tolušić et al., 2014.; Tomić, 2015., 2016. i drugi). Većina spomenutih radova istraživala je studentsku populaciju (također milenijalisti) i zabilježeni su statistički značajni rezultati. Slijedom analize pristupa istraživanju ekoloških namjera i u ovom radu korištena je teorija planiranog ponašanja.

\section{METODOLOGIJA ISTRAŽIVANJA}

\section{1 Model i hipoteze istraživanja}

Prema modelu koji nudi teorija planiranog ponašanja donošenje odluka vođeno je racionalnim vrednovanjem posljedica ponašanja i sadrži četiri prediktora ponašanja. Pritom stavovi prema određenom ponašanju, subjektivne norme i percipirana kontrola ponašanja ne determiniraju ponašanje izravno, već posredno, putem namjera ponašanja. U nastavku su detaljnije obrazložene osnovne i dodatne varijable modela prilagođenog za ovo istraživanje.

Stavovi prema ponašanju. Prema modelu očekivanja i vrijednosti stav prema ponašanju određen je skupom dostupnih ponašajnih uvjerenja. Tako pojedinci daju prednost ponašanjima za koja su uvjereni da imaju poželjne posljedice i formiraju nepovoljne stavove prema ponašanjima koja asociraju s neželjenim posljedicama (Ajzen, 1991:191). Istraživanja su potvrdila povezanost između stavova i namjera ponašanja i u području ekoloških ponašanja. Primjerice, Bamberg i 
Möser (2007:19-20) kroz metaanalizu utvrdili su srednje jaku prosječnu korelaciju između stavova i ekološkog ponašanja $(r=0,42)$. Istraživanja domaćih autora također su pokazala da stavovi prema ponašanju predstavljaju statistički značajan prediktor namjera kupnje ekoloških proizvoda (hrane). Primjerice, Jeger et al. (2014:360) utvrdili su korelacije stavova i namjera kupnje u rasponu od $r=$ 0,203 do $r=0,410$ (pri $p<0,01$ ), a Tomić et al. (2015:16) da stavovi predstavljaju treći najvažniji prediktor namjera kupnje iza subjektivnih normi i percipirane kontrole ponašanja $(\beta=0,246, \mathrm{t}=$ $2,93, p<0,05)$. Slijedom navedenog postavljena je sljedeća hipoteza:

H1: Stavovi zabrinutosti za okoliš povezani su i pozitivno utječu na namjere kupnje i uporabe ekoloških proizvoda i usluga.

Subjektivne norme predstavljaju percipirani društveni pritisak na uključivanje ili neuključivanje $\mathrm{u}$ određeno ponašanje i determinirane su skupom normativnih uvjerenja koja se tiču očekivanja važnih pojedinaca ili skupina na koje se referiramo, poput supružnika, obitelji, prijatelja, šefova, suradnika i sl. (http://people.umass.edu/aizen/index.html). lako su metaanalize primjene teorije planiranog ponašanja pokazale da subjektivne norme predstavljaju manje važnu varijablu (primjerice, kod Steinmetzet al.(2016:224) subjektivne norme imaju najnižu ponderiranu prosječnu veličinu učinka među osnovnim varijablama teorije, a kod Armitage i Conner (2001:481) najnižu prosječnu korelaciju s namjerama ponašanja), domaći autori, primjerice, Tomić et al. (2015:16), pomoću regresijske analize utvrdili su da subjektivne norme imaju najvažniji (srednje snažan) utjecaj na namjere ponašanja ( $\beta=0,443, t=5,65, p<0,05)$, a Martić Kuran i Mihić (2014:189) nešto slabiji utjecaj $(\beta=0,328, t=6,809, p<0,01)$. Temeljem navedenog postavljena je sljedeća hipoteza:

H2. Subjektivne norme povezane su i pozitivno utječu na namjere kupnje i uporabe ekoloških proizvoda i usluga.

Percipirana kontrola ponašanja. Među uvjerenjima koja određuju namjere je i skup koji obuhvaća prisutnost ili odsutnost potrebnih resursa ili prilika. Što više resursa i prilika pojedinac vjeruje da posjeduje te što je manje prepreka koje anticipira, vjerojatnije je da će imati veću percipiranu kontrolu nad ponašanjem (Ajzen, 1991:196). U kontekstu kupnje i uporabe ekoloških proizvoda ili usluga vrlo važan čimbenik predstavlja cijena (Nefat, 2015:40), stoga se očekuje da percipirana financijska situacija pridonese predviđanju namjera ponašanja. Slična očekivanja dokazana su i ranijim istraživanjima, primjerice, Bamberg i Möser (2007:20) metaanalizom su utvrdili prosječni koeficijent $r=0,30$, tj. slabu korelaciju, između percipirane kontrole ponašanja i ekoloških ponašanja. Nadalje, Tomić et al. (2015:16) regresijskom su analizom utvrdili da percipirana kontrola ponašanja ima statistički značajan (slab) utjecaj na namjere ponašanja $(\beta=0,273, t=3,53 ; p<0,05)$, a Martić Kuran i Mihić (2014:189) nešto slabiji negativan utjecaj percipirane financijske situacije ( $\beta$ $=-0,161, t=-3,751, p<0,01)$. Slijedom analiziranog postavljena je sljedeća hipoteza:

H3. Percipirana financijska situacija povezana je i pozitivno utječe na namjere kupnje i uporabe ekoloških proizvoda i usluga.

Da bi se što preciznije utvrdili prediktori namjera kupnje, a posljedično i ekološki osviještenih ponašanja, u model teorije planiranog ponašanja uvrštene su dodatne varijable i to znanje $o$ tematici ekologije i svijest o važnosti očuvanja okoliša. 
Znanje se definira kao činjenice, informacije i vještine stečene kroz iskustvo ili obrazovanje, odnosno teorijskoilipraktično razumijevanjeodređenetemeilisubjekta(Brucks, 1985, citiranouAertsensetal., 2011:1356). Bamberg i Möser (2007:22) utvrdili su u metaanalizi da znanje uz svijest ima važnu ulogu u ekološkim problemima kao druga najvažnija neizravna odrednica ekološkog ponašanja. Pritom je utvrđeno da znanje i svijest nisu samo povezani s internom razinom odgovornosti, društvenim normama i osjećajem krivnje, već izravno utječu i na razinu percipirane kontrole ponašanja, kao i na stavove prema odabiru ekološkog ponašanja. Aertsens et al. (2011:1371) empirijski su dokazali da subjektivno znanje ima veći utjecaj na potrošnju organske hrane od objektivnog znanja $(\beta=0,30, \mathrm{t}=6,12, p<0,01$ prema $\beta=0,12, \mathrm{t}=2,87, p<0,01)$, dok su Martić Kuran i Mihić (2014:189) utvrdili slab pozitivan utjecaj znanja na namjere kupnje ekološke hrane $(\beta=0,170$, $\mathrm{t}=3,779, p<0,01)$. Stoga je u ovom radu postavljena sljedeća hipoteza:

H4. Znanje o tematici ekologije povezano je i pozitivno utječe na namjere kupnje i uporabe ekoloških proizvoda i usluga.

Svijest se obično definira kao sposobnost donošenja odluka koje nisu predmet slučajnog odabira (Merikle, 1984:449). Svijest kao dodatnu varijablu modela planiranog ponašanja uvrštava više autora, primjerice, Heath i Gifford (2002:2156i 2178) u model su ukomponirali svijest o problemima koje stvara korištenje automobila te utvrdili da je riječ o statistički značajnom prediktoru namjere korištenja autobusnog prijevoza $(\beta=0,17, t=2,72, p<0,01)$. Nadalje, metaanaliza autora Bamberg i Möser (2007:22) potvrdila je da svijest o problemu ima važan ukupni učinak na ponašanja, iako pretežno posredno kroz snažnu povezanost s osjećajima krivnje i moralnih normi. Martić Kuran i Mihić (2014:189) utvrdili su slab pozitivan utjecaj svijesti o zdravlju $(\beta=0,221, t=4,364, p<0,01)$. Slijedom analiziranog u ovom radu je postavljena sljedeća hipoteza:

H5. Svijest o važnosti očuvanja okoliša povezana je i pozitivno utječe na namjere kupnje i uporabe ekoloških proizvoda i usluga.

S obzirom na to da je u većini studija mladih potrošača (pretežito studenata) spomenutih u točki 2.2. utvrđeno da su svjesniji i odgovorniji u pogledu važnosti zaštite okoliša, te je vjerojatnije da će bolje razumjeti koncept održive potrošnje i njen utjecaj na okoliš i društvo u odnosu na starije dobne skupine (Joshi i Rahman, 2016:454), kao i da žene imaju izraženije ekološke stavove, za sve hipoteze će se istraživati razlike u odnosu na dob, spol i stručnu spremu.

Postavljene hipoteze prikazane su i u sklopu konceptualnog modela istraživanja na shemi 1. 
Shema 1. Konceptualni model istraživanja

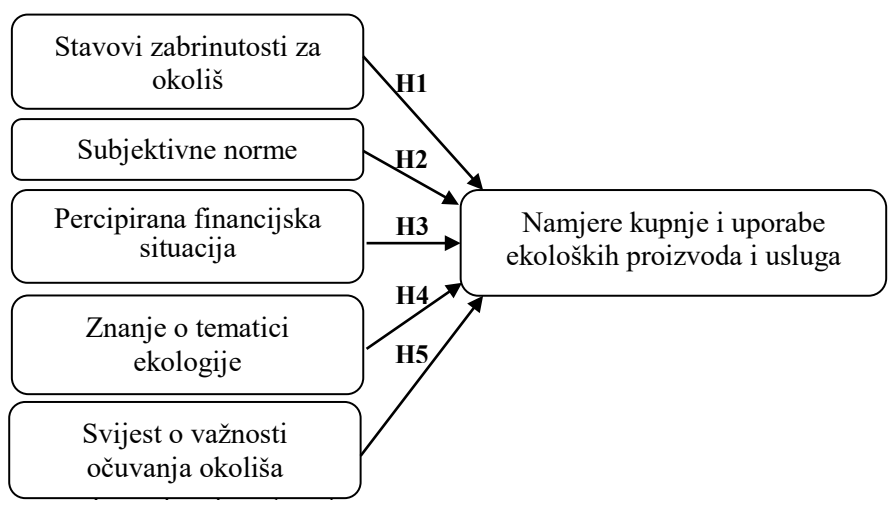

Izvor: izrada autora (modificirano prema Ajzen, 1991:182)

\section{2 Instrument, uzorak i provedba istraživanja}

U sklopu dokazivanja postavljenih hipoteza provedeno je empirijsko istraživanje. Instrument korišten u sklopu istraživanja predstavlja upitnik kojim su obuhvaćene sve komponente konceptualnog modela istraživanja. Pri formiranju tvrdnji za ljestvice pojedinih varijabli modela predviđanja planiranog ponašanja korišteni su različiti izvori, primjerice, za stavove zabrinutosti za okoliš prilagođene su tvrdnje iz istraživanja institucije Natural Marketing Institute o najvažnijim okolišnim problemima ispitanika (Ottman, 2011:3) te istraživanja TerraChoice Environmental Marketing Inc. (2007:2-4). Kod uobličavanja ljestvice za percipiranu financijsku situaciju, subjektivne norme, znanja o tematici ekologije i svijesti o važnosti očuvanja okoliša konzultirani su: Chaudhary (2018:185), Joshi i Rahman (2016:460), Aertsens et al. (2011:1362), Martić Kuran i Mihić, (2014:196), dok su tvrdnje za utvrđivanje namjera kupnje ekoloških proizvoda i usluga formulirane slijedom upitnika u istraživanju LOHAS segmenta potrošača (Ottman, 2011:8). Pored ovih izvora, ljestvice su dopunjene i samostalno razvijenim tvrdnjama. S obzirom na to da nije provedeno pokusno testiranje finaliziranog upitnika, ovdje je riječ o indikativnom istraživanju.

Upitnik sadrži ukupno 50 tvrdnji za ispitivanje svih varijabli, kao i tri demografske (kontrolne) varijable (spol, dob i stručna sprema), te zbog svog obima nije priložen ovom radu. ${ }^{1}$ Za sve varijable (izuzev demografskih) korištena je intervalna (Likertova) ljestvica s pet stupnjeva (od 1: 'uopće se ne slažem' do 5: 'potpuno se slažem'). Upitnik za online popunjavanje pripremljen je uz pomoć LimeSurvey alata. Upitnik je distribuiran e-maila na ukupno 722 adrese studenata, bivših studenata i zaposlenika Veleučilišta u Rijeci, a dijelom i uz pomoć sudionika društvenih mreža autora rada. Istraživanjem su prikupljeni odgovori od 120 ispitanika, što predstavlja odaziv od 16,6 \%. Anketiranje je provedeno u lipnju i srpnju 2018. godine. U nastavku su prikazane demografske karakteristike uzorka.

\footnotetext{
Cjelovit upitnik dostupan na zahtjev upućen autorima.
} 
Tablica 1. Demografske karakteristike uzorka

\begin{tabular}{|c|c|c|c|c|c|}
\hline Karakteristike & $\mathbf{N}$ & $\%$ & Karakteristike & $\mathbf{N}$ & $\%$ \\
\hline Spol & 120 & & Dob (godine) & 120 & \\
\hline Ž & 72 & 60 & $<18$ & 0 & 0 \\
\hline M & 48 & 40 & $19-24$ & 59 & 49,17 \\
\hline Stručna sprema & 120 & & $25-29$ & 22 & 18,33 \\
\hline Niža & 0 & $/$ & $30-39$ & 20 & 16,67 \\
\hline Srednja & 42 & 35 & $40-49$ & 13 & 10,83 \\
\hline Viša & 50 & 41,67 & $50-59$ & 5 & 4,17 \\
\hline Visoka (uklj. mr. i dr.) & 28 & 23,33 & $>60$ & 1 & 0,83 \\
\hline \multicolumn{7}{|c|}{ Izvor: istraživanje autora } \\
\hline
\end{tabular}

\section{3 Obrada rezultata istraživanja}

Za analizu prikupljenih empirijskih podataka korišten je statistički alat GNU PSPP Statistical Analysis Software (Release 0.9.0-g3a3d58, verzija 2014.). U analizi su primijenjene metode deskriptivne i inferencijalne statistike te bivarijatne statističke analize. Provjera pouzdanosti mjernih ljestvica provedena je pomoću Cronbachova $\alpha$-koeficijenta, a za provjeru povezanosti postavljenih hipoteza korelacijska i regresijska analiza.

\section{REZULTATI ISTRAŽIVANJA}

Radi usporedbe rezultata u odnosu na demografske (kontrolne) varijable provedene su analize i to t-test za nezavisne uzorke i ANOVA. U tablici 2 prikazani su samo statistički značajni rezultati analize deskriptivne statistike prema kontrolnim varijablama.

Tablica 2. Statistički značajne razlike s obzirom na spol i dob

\begin{tabular}{|c|c|c|c|c|c|c|}
\hline \multirow{2}{*}{$\begin{array}{l}\text { Spol } \\
\text { Varijabla (koncept) }\end{array}$} & \multicolumn{2}{|c|}{ Žene $(\mathrm{N}=72)$} & \multicolumn{2}{|c|}{ Muškarci $(\mathrm{N}=48)$} & \multirow{2}{*}{ T-test } & \multirow{2}{*}{ Sig. } \\
\hline & A.S. & St. dev. & A.S. & St. dev. & & \\
\hline Stavovi zabrinutosti za okoliš & 3,91 & 0,48 & 3,58 & 0,48 & $-3,60$ & $0,000^{* *}$ \\
\hline Znanje o tematici ekologije & 3,07 & 0,72 & 3,22 & 0,55 & 1,19 & $0,040^{*}$ \\
\hline Dob (raspon godina) & \multicolumn{2}{|c|}{$<30(\mathrm{~N}=81)$} & \multicolumn{2}{|c|}{$\geq 30(\mathrm{~N}=39)$} & \multirow{2}{*}{ T-test } & \multirow{2}{*}{ Sig. } \\
\hline Varijabla (koncept) & A.S. & St. dev. & A.S. & St. dev. & & \\
\hline Znanje o tematici ekologije & 3,01 & 0,63 & 3,38 & 0,66 & 2,99 & $0,003^{* *}$ \\
\hline $\begin{array}{l}\text { Svijest o važnosti očuvanja } \\
\text { okoliša }\end{array}$ & 3,20 & 0,45 & 3,52 & 0,41 & 3,70 & $0,000^{* *}$ \\
\hline $\begin{array}{l}\text { Namjere kupnje i uporabe } \\
\text { ekoloških proizvoda i usluga }\end{array}$ & 3,34 & 0,48 & 3,60 & 0,45 & 2,84 & $0,005^{* *}$ \\
\hline
\end{tabular}

Napomena: A. S.= aritmetička sredina; St. dev. = standardna devijacija; Sig. = pouzdanost; ** značajnost na razini 0,01; *značajnost na razini 0,05 
Rezultati istraživanih koncepata, u odnosu na kontrolne (demografske) varijable, pokazali su da statistički značajne razlike ( $p<0,01)$ postoje u stavovima zabrinutosti za okoliš, gdje žene iskazuju veću razinu zabrinutosti od muškaraca te kod znanja o ekologiji, gdje su muškarci 'zabrinutiji' od žena. Nadalje, statistički značajne razlike postoje i kod znanja o tematici ekologije, svijesti o važnosti očuvanja okoliša te namjera kupnje i uporabe ekoloških proizvoda i usluga, gdje mlađi ispitanici (< 30 godina) imaju lošije rezultate u odnosu na starije dobne skupine ( $\geq 30$ godina). Radi provjere pouzdanosti primijenjenih mjernih ljestvica korišten je Cronbachov $\alpha$-koeficijent. Rezultati su vidljivi u tablici 3.

Tablica 3. Pouzdanost mjernih ljestvica mjerena Cronbachovim $\alpha$-koeficijentom

\begin{tabular}{|c|c|c|}
\hline Varijabla (koncept) & Broj tvrdnji & $\begin{array}{c}\text { Cronbachov } \\
\alpha \text {-koeficijent }\end{array}$ \\
\hline Stavovi zabrinutosti za okoliš & 16 & 0,85 \\
\hline Subjektivne norme & 5 & 0,80 \\
\hline Percipirana financijska situacija & 6 & $-0,48^{*}$ \\
\hline Znanje o tematici ekologije & 5 & 0,82 \\
\hline Svijest o važnosti očuvanja okoliša & 4 & 0,69 \\
\hline Namjere kupnje i uporabe ekoloških proizvoda i usluga & 14 & 0,80 \\
\hline
\end{tabular}

* Cronbachov $\alpha$-koeficijent za koncept 'Percipirana financijska situacija' nije prihvatljiv, te je ova varijabla isključena iz daljnje analize.

Izvor: istraživanje autora

Iz analize pouzdanosti vidljivo je da vrijednost Cronbachova koeficijenta za svijest o važnosti očuvanja okoliša ima nižu ali prihvatljivu razinu pouzdanosti, ${ }^{2}$ dok je iz daljnje analize zbog niske pouzdanosti isključena varijabla percipirane financijske situacije. Koeficijenti za ostale varijable su oko razine 0,80 , što ukazuje da su mjerenja tih varijabli vrlo pouzdana. Radi provjere postavljenih hipoteza provedena je korelacijska analiza. $U$ tablici 4 prikazani su samo rezultati analize za varijable za koje je utvrđena statistički značajna razlika u odnosu na demografske karakteristike (prikaz razlika dat je u tablici 2).

2 Prema Leech et al. (2005:67) vrijednosti Cronbachova koeficijenta trebale bi biti iznad 0,70, no prihvaćaju se i razine od 0,60 do 0,69, što je obično znak manjeg broja varijabli u konceptu. 
Tablica 4. Korelacijska analiza povezanosti među postavljenim hipotezama (skraćeni prikaz)

\begin{tabular}{|c|c|c|}
\hline Varijable (koncepti) & $\begin{array}{c}\text { Pearsonova } \\
\text { korelacija }\end{array}$ & Sig. (2-strano) \\
\hline H1: STAV $\leftrightarrow$ NAMJ & 0,28 & $0,002^{* *}$ \\
\hline H1: STAV $\leftrightarrow$ NAMJ žene & 0,34 & $0,003^{* *}$ \\
\hline H1: STAV $\leftrightarrow$ NAMJ muškarci & 0,14 & 0,357 \\
\hline H2: SUNORM $\leftrightarrow$ NAMJ & 0,04 & 0,701 \\
\hline H4: ZNA $\leftrightarrow$ NAMJ & 0,20 & $0,030^{*}$ \\
\hline H4: ZNA $\leftrightarrow$ NAMJ žene & 0,19 & 0,102 \\
\hline H4: ZNA $\leftrightarrow$ NAMJ muškarci & 0,24 & 0,094 \\
\hline H4: ZNA $\leftrightarrow$ NAMJ $\geq 30$ god. & 0,24 & 0,133 \\
\hline H4: ZNA $\leftrightarrow$ NAMJ < 30 god. & 0,09 & 0,414 \\
\hline H5: SVIJ $\leftrightarrow$ NAMJ & 0,45 & $0,000^{* *}$ \\
\hline H5: SVIJ $\leftrightarrow$ NAMJ $\geq 30$ god. & 0,43 & $0,006^{* *}$ \\
\hline H5: SVIJ $\leftrightarrow$ NAMJ < 30 god. & 0,39 & $0,000^{* *}$ \\
\hline
\end{tabular}

Legenda: STAV = stavovi zabrinutosti za okoliš; SUNORM = subjektivne norme; ZNA = znanje o tematici ekologije; SVIJ = svijest o važnosti očuvanja okoliša; NAMJ = namjere kupnje i uporabe ekoloških proizvoda i usluga;

** značajnost na razini 0,01 ; *značajnost na razini 0,05

Izvor: istraživanje autora

Rezultati korelacijske analize pokazuju statistički značajne (slabe) veze između stavova zabrinutosti za okoliš te namjera kupnje i uporabe ekoloških proizvoda i usluga $(r=0,28$, pri $p<0,01)$, čime je potvrđena hipoteza $\mathrm{H}$ 1. Ispitivanjem korelacija između stavova zabrinutosti za okoliš te namjera kupnje i uporabe ekoloških proizvoda i usluga kod obaju spolova utvrđeno je da postoji statistički značajna (slaba) povezanost samo kod ženskih ispitanika $(r=0,34$, pri $p<0,01)$, dok kod muškaraca ta povezanost nije statistički značajna $(r=0,14$, pri $p=0,357)$. Veza između subjektivnih normi i namjera kupnje i uporabe ekoloških proizvoda i usluga nije statistički značajna, pa slijedi da se hipoteza $\mathrm{H} 2$ odbacuje. U pogledu znanja o tematici ekologije kao prediktora namjera kupnje i uporabe ekoloških proizvoda i usluga utvrđena je slaba povezanost $(r=0,20$, pri $p<0,05)$, dok za podskupine s obzirom na spol i dob nisu utvrđene statistički značajne povezanosti. Ovime se prihvaća hipoteza H4. Nadalje, povezanost svijesti o važnosti očuvanja okoliša i namjera kupnje i uporabe ekoloških proizvoda i usluga statistički je značajna i jaka $(r=0,45$, pri $p<0,01)$. Zasebnom korelacijskom analizom povezanosti svijesti o važnosti očuvanja okoliša i namjera kupnje i uporabe ekoloških proizvoda i usluga kod mlađih (< 30 godina) i starijih ispitanika ( $\geq 30$ godina) utvrđena je snažnija korelacija $(r=0,43$, pri $p<0,01$, prema $r=0,39$, pri $p<0,01)$ kod starijih ispitanika. Slijedi da se hipoteza H5 prihvaća (za obje dobne skupine), no vidljivo je da mlađi ispitanici imaju slabiju svijest o važnosti očuvanja okoliša od starijih. 
Da bi se utvrdila pozitivna linearna veza između nezavisnih varijabli i namjera kupnje i uporabe ekoloških proizvoda i usluga kao zavisne varijable, provedena je linearna regresijska analiza. Radi provjere preduvjeta reprezentativnosti rezultata regresijske analize provedena je analiza normalnosti distribucije (tablica 5).

Tablica 5. Provjera normalnosti distribucije varijabli u regresijskom modelu

\begin{tabular}{|c|c|c|c|c|}
\hline Varijable & A.S. & St. dev. & Asimetrija & Zaobljenost \\
\hline Stavovi zabrinutosti za okoliš & 3,78 & 0,50 & $-0,43$ & $-0,02$ \\
\hline Subjektivne norme & 2,43 & 0,66 & 0,19 & 0,04 \\
\hline Znanje o tematici ekologije & 3,13 & 0,66 & 0,03 & 0,97 \\
\hline Svijest o važnosti očuvanja okoliša & 3,75 & 0,59 & $-0,65$ & 3,38 \\
\hline $\begin{array}{c}\text { Namjere kupnje i uporabe ekoloških } \\
\text { proizvoda i usluga }\end{array}$ & 3,42 & 0,48 & $-0,36$ & 0,83 \\
\hline
\end{tabular}

Napomena: A. S.= aritmetička sredina; St. dev. = standardna devijacija

Izvor: istraživanje autora

Uočava se blaga negativna asimetrija kod varijabli stavovi zabrinutosti za okoliš, svijest o važnosti očuvanja okoliša i namjere kupnje i uporabe ekoloških proizvoda i usluga, dok preostale varijable imaju blago pozitivnu asimetriju, no svi koeficijenti asimetrije unutar su granica prihvatljivosti za normalnu distribuciju. ${ }^{3}$ Koeficijenti korelacije u regresijskom modelu prikazani su u tablici 6.

Tablica 6. Koeficijenti korelacije u regresijskom modelu (sažetak modela)

\begin{tabular}{|c|c|c|c|}
\hline$R$ & $R^{2}$ & Prilagođeni $R^{2}$ & $\begin{array}{c}\text { Standardna pogreška } \\
\text { procjene }\end{array}$ \\
\hline 0,47 & 0,22 & 0,19 & 0,43 \\
\hline
\end{tabular}

Koeficijent multiple korelacije R, uz istovremenu prisutnost svih nezavisnih varijabli (prediktora), iznosi 0,47 , pa se može zaključiti da postoji srednja razina povezanosti između nezavisnih i zavisne varijable. ${ }^{4}$ Prema koeficijentu determinacije $\left(R^{2}=0,22\right)$ varijable u modelu dijele $22 \%$ zajedničkih faktora. To znači da se $22 \%$ varijance (informacija) namjera kupnje i uporabe ekoloških proizvoda i usluga može predvidjeti (objasniti) nezavisnim varijablama.

3 Preporučene vrijednosti koeficijenta asimetrije su između $+1.0 \mathrm{i}-1.0$, što označava granice normalnosti distribucije podataka (Leech et al., 2005:21). Iz uvida u histograme razvidno je da su tri varijable asimetrične prema lijevo, a dvije prema desno, tj. da imaju grubi oblik normalne distribucije.

4 Koeficijenti multiple korelacije $(R)$ interpretiraju se slično kao i koeficijenti korelacije $(r)$, tj. niska razina povezanosti $(R) \geq 0,14<0,36(r=\geq 0,1<0,3)$; srednja razina $(R) \geq 0,36<0,51(r=\geq 0,3<0,5)$ visoka razina $(R) \geq 0,51<0,70+(r=$ $\geq 0,5<0,7)$ i vrlo visoka $(R) \geq 0,7(r=\geq 0,7)$ prema Leech et al., 2005:56. 
Tablica 7. Analiza varijance (ANOVA) za regresijski model

\begin{tabular}{|c|c|c|c|c|c|}
\hline & $\begin{array}{c}\text { Zbroj } \\
\text { kvadrata }\end{array}$ & $\begin{array}{c}\text { Stupnjevi } \\
\text { slobode }\end{array}$ & $\begin{array}{c}\text { Kvadrat } \\
\text { prosjeka }\end{array}$ & F & Sig. \\
\hline Regresija & 6,12 & 4 & 1,53 & 8,18 & 0,000 \\
Ostatak & 21,53 & 115 & 0,19 & & \\
Ukupno & 27,66 & 119 & & & \\
\hline \multicolumn{7}{|c|}{ Izvor: istraživanje autora }
\end{tabular}

Analizom varijance (tablica 7) utvrđeno je da su rezultati statistički značajni, $F(2,120)=8,18$, $p<0,01$. To znači da stavovi zabrinutosti za okolišs, subjektivne norme, znanje o tematici ekologije i svijest o važnosti očuvanja okoliša značajno predviđaju namjere kupnje i uporabe ekoloških proizvoda i usluga. Regresijske koeficijente i njihovu značajnost u regresijskom modelu sadrži tablica 8.

Tablica 8. Regresijski koeficijenti i pokazatelji kolinearnosti u regresijskom modelu

\begin{tabular}{|l|c|c|c|c|c|}
\hline \multirow{2}{*}{ Varijable } & \multicolumn{2}{|c|}{$\begin{array}{c}\text { Nestandardizirani } \\
\text { koeficijent }\end{array}$} & $\begin{array}{c}\text { Standardizirani } \\
\text { koeficijent }\end{array}$ & \multirow{2}{*}{$\mathrm{t}$} & \multirow{2}{*}{ Sig. } \\
\cline { 2 - 4 } & $\mathrm{B}$ & $\begin{array}{c}\text { Standardna } \\
\text { pogreška }\end{array}$ & \multicolumn{2}{|c|}{ Beta } & \\
\hline (Konstanta) & 1,72 & 0,37 & 0,00 & 4,62 & 0,000 \\
Stavovi zabrinutosti za okoliš & 0,06 & 0,09 & 0,06 & 0,48 & 0,499 \\
Subjektivne norme & 0,03 & 0,06 & 0,04 & 0,52 & 0,606 \\
Znanje o tematici ekologije & 0,05 & 0,06 & 0,06 & 0,74 & 0,464 \\
Svijest o važnosti očuvanja okoliša & 0,33 & 0,08 & 0,41 & 4,15 & $0,000^{*}$ \\
\hline
\end{tabular}

Napomena: *značajnost na razini 0,01

Izvor: istraživanje autora

S obzirom na to da su nezavisne varijable u promatranom regresijskom modelu mjerene na istoj ljestvici (ocjenama od 1 do 5), za utvrđivanje uzročno-posljedične veze interpretirani su nestandardizirani (B) koeficijenti. Prema rezultatima u tablici 8 (B koeficijenti) povećanje rezultata na ljestvici svijesti o važnosti očuvanja okoliša za jedan bod prosječno povećava rezultat na ljestvici namjere kupnje i uporabe ekoloških proizvoda i usluga za 0,33 bodova. Nadalje, razvidno je da nezavisna varijabla svijest o važnosti očuvanja okoliša značajno i pozitivno utječe na namjere kupnje i uporabe ekoloških proizvoda i usluga, budući da se vrijednost t-testa značajno razlikuje od nule, te je signifikantna pri $p<0,01$ (Hair et al. 2010:212). Ovi rezultati dodatno potvrđuju hipotezu H5, te ukazuju na intenzitet kojim svijest o važnosti očuvanja okoliša pozitivno i statistički značajno utječe na namjere kupnje i uporabe ekoloških proizvoda i usluga, dok za ostale hipoteze nije potvrđena korelacijom dokazana povezanost. 


\section{ZAKLJUČNA RAZMATRANJA}

\section{1 Zaključci istraživanja}

Rezultati upućuju da je glavna hipoteza rada djelomično uspješno provjerena. Naime, primjenom teorije planiranog ponašanja utvrđeno je da postoji statistički značajna povezanost stavova zabrinutosti za okoliš, znanja o tematici ekologije te svijesti o važnosti očuvanja okoliša i namjera kupnje i uporabe ekoloških proizvoda i usluga, no ne i preostalih ispitivanih varijabli (subjektivne norme i percipirana kontrola ponašanja, odnosno percipirana financijska situacija). Pritom za subjektivne norme postoji statistički ne-značajna povezanost. Pored toga svijest o važnosti očuvanja okoliša izravno i pozitivno utječe na namjere kupnje i uporabe ekoloških proizvoda i usluga.

Nadalje, utvrđeno je da ženski ispitanici imaju više izražene stavove zabrinutosti za okoliš od muških ispitanika, što je u skladu s ranijim rezultatima istraživanja (primjerice Uddin i Khan, 2016:93). Potvrđene su i pretpostavke o različitim razinama rezultata ovisno o dobi ispitanika i to kod varijabli znanja o tematici ekologije, svijesti o važnosti očuvanja okoliša i namjera kupnje i uporabe ekoloških proizvoda i usluga. Te razlike su statistički značajne i pritom su mlađi ispitanici pokazali niže prosječne rezultate od starijih ispitanika. Ovi rezultati su u skladu s ranijim zaključcima koji govore o nekonzistentnosti rezultata istraživanja dobnih diferencijacija (primjerice metaanaliza Wiernik et al., 2013). Istovremeno niži prosječni rezultati kod mladih u Hrvatskoj suprotni su postavkama o milenijalistima kao potencijalno svjesnijom i odgovornijom dobnom skupinom (primjerice Joshi i Rahman, 2016:454).

Prema saznanjima autora teorija planiranog ponašanja koja uz osnovne koristi i dodatne prediktore namjera ponašanja (znanje o tematici ekologije i svijest o važnosti očuvanja okoliša) dosad nije primijenjena u istraživanjima namjera ekoloških ponašanja mlađe populacije u Republici Hrvatskoj, koja se kao najmlađa članica EU-a suočava s politikama koje snažno ističu značaj očuvanja okoliša. S obzirom na rezultate ovog istraživanja poželjno je osnažiti društvene aktivnosti usmjerene ka jačanju razumijevanja i svijesti mladih u Hrvatskoj o ekološkim problemima i važnosti očuvanja okoliša.

\subsection{Ograničenja istraživanja}

Ograničenja istraživanja ovog rada mogu se promatrati i kao smjernice za buduća istraživanja. Naime, s obzirom na nisku razinu pouzdanosti mjernih ljestvica varijable percipirane kontrole ponašanja, odnosno percipirane financijske situacije, potrebno je dodatno unaprijediti tvrdnje koje čine tu ljestvicu (poželjno kroz pokusno testiranje). Pritom treba uvažiti da mlađi ispitanici često nemaju potpuni uvid u obiteljsku financijsku situaciju, pa su i njihove percepcije potencijalno različite od starijih $u$ istoj financijskoj situaciji. Treba istaknuti i da su (prvenstveno, zbog dostupnosti) uzorak činili pretežno studenti, pa uzorak ne odražava stvarnu strukturu mladih u Hrvatskoj, barem prema dobi i stručnoj spremi.

Pored toga, u ovom istraživanju nije uključena varijabla (ekološkog) ponašanja koja je sastavnica osnovnog modela planiranog ponašanja. Naime, zbog većeg broja (14) varijabli kojima su mjerene namjere kupnje i uporabe ekoloških proizvoda i usluga bilo bi nepraktično s gotovo istim varijablama 
ispitivati i prošla ponašanja, budući da bi to značajno povećalo dužinu upitnika i potencijalno smanjilo odaziv ispitanika. Ipak i u ovom kontekstu moguće je u upitniku primijeniti neke od općenitih varijabli za ispitivanje namjera i ponašanja, koje su prostorno i vremenski prihvatljivije. Primjerice, Chaudhary (2018:185), za namjere i ponašanja koristi ukupno osam varijabli (pitanja).

\section{LITERATURA}

Aertsens, J., Mondelaers, K., Verbeke, W., Buysse, J., Van Huylenbroeck, G. (2011) The influence of subjective and objective knowledge on attitude, motivations and consumption of organic food, British Food Journal, Vol. 113, Issue 11, p. 1353-1378. https://doi.org/10.1108/00070701111179988

Ajzen, I. (1991) The Theory of Planned Behavior, Organizational behavior and human decision processes, Vol 50, p. 179211. https://doi.org/10.1016/0749-5978(91)90020-T

Ajzen, l., http://people.umass.edu/aizen/index.html, 10. 11. 2018.

Armitage, C. J. i Conner, M. (2001) Efficacy of the Theory of Planned Behaviour: A metaanalytic review, British Journal of Social Psychology, Vol. 40, p. 471-499. https://doi.org/10.1348/014466601164939

Bamberg, S. i Möser, G. (2007) Twenty years after Hines, Hungerfold and Tomera: A new metaanalysis of psycho-social determinants of pro-environmental behaviour, Journal of Environmental Psychology, Vol 27, p. 14-25. https://doi. org/10.1016/j.jenvp.2006.12.002

Bryman, A., Cramer, D. (2005) Quantitative Data Analysis with SPSS 12 and 13: A Guide for Social Scientists, London, New York: Routledge. https://doi.org/10.4324/9780203498187

Chaudhary, R. (2018) Green buying behavior in India: an empirical analysis, Journal of Global Responsibility, Vol. 9, Issue 2, p.179-192. https://doi.org/10.1108/JGR-12-2017-0058

Dangelico, R. M., Vocalelli, D. (2017) “Green Marketing” An analysis of definitions, strategy steps, and tools thorugh a systematic review of the literature, Journal of Cleaner Production, Vol. 165, p. 1263-1279. https://doi.org/10.1016/j. jclepro.2017.07.184

Državni statistički zavod - DZS (2013) Popis stanovništva, kućanstava i stanova 2011, Stanovništvo prema spolu i starosti, Zagreb, www.dzs.hr

European Commision, Special Eurobarometer (2017) The attitudes of European citizens towards environment, http:// ec.europa.eu/commfrontoffice/publicopinion, 7. 11. 2018.

European Union (2018) Energy, transport and environment indicators, 2018 edition, Luxembourg, https://ec.europa.eu/ eurostat/, 25. 10. 2018.

Eurostat - population https://ec.europa.eu/eurostat/web/population-demography-migration-projections/data/maintables, 12. 11. 2018.

Hair, J. F., Black, W. C., Babin, B. J., Anderson, R. E. (2010) Multivariate Data Analysis: A Global Perspective, 7th Edition, New Yersey, Upper Saddle River: Pearson Education Inc.

Heath, Y., i Gifford, R. (2002) Extending the Theory of Planned Behavior: Predicting the Use of Public Transportation, Journal of Applied Social Psychology, Vol. 32, Issue 10, p. 2154-2189. https://doi.org/10.1111/j.1559-1816.2002. tb02068.x

Jeger, M., Ham, M., Leko, V. (2014) Attitudes toward Green Food Purchase among Students: Evidence from Eastern Croatia, 3. međunarodni znanstveni simpozij Gospodarstvo istočne Hrvatske - vizija i razvoj Sveučilište J. J. Strossmayera u Osijeka, Ekonomski fakultet u Osijeku, p. 354-363

Joshi, Y. i Rahman, Z. (2016) Predictors of young consumer's green purchase behaviour, Management of Environmental Quality: An International Journal, Vol. 27, Issue 4, p. 452-472. https://doi.org/10.1108/MEQ-05-2015-0091

Kotler, P. (2011) Reinventing Marketing to Manage the Environmental Imperative, Journal of Marketing, Vol. 75, p. 132135. https://doi.org/10.1509/jmkg.75.4.132 
Kotler, P. i Armstrong, G. (2012) Principles of Marketing, 14th ed., Pearson Education, Inc., publishing as Prentice Hall, One Lake Street, Upper Saddle River, New Jersey

Kumar, P. (2016) State of green marketing research over 25 years (1990-2014) Literature survey and cassification, Marketing Intelligence \& Planning, Vol. 34, Issue 1, p. 137-158. https://doi.org/10.1108/MIP-03-2015-0061

Lee, K. (2008) Oppurtunities for green marketing: young consumers, Marketing Intelligence \& Planning, Vol. 26, Issue 6, p. 573-586. https://doi.org/10.1108/02634500810902839

Leech, N. L., Barett, K. C., Morgan, G. A. (2005) SPSS for Intermediate Statistics: Use and Interpretation, 2nd Edition, Lawrence Erlbaum Associates Publishers, New Jersey

Martić Kuran, L., Mihić, M. (2014) Primjena teorije planiranog ponašanja u kupovini ekološke hrane, Market-Tržište, Vol. 26, Issue 2, p. 179-197

Merikle, P.M. (1984) Toward a definition of awareness, Bulletin of the Psychonomic Society, Vol. 22, Issue 5, p. 449-450. https://doi.org/10.3758/BF03333874

Naderi, l., Van Steenburg, E. (2018) Me first, then the environment: young Millennials as green consumers, Young Consumers, Vol. 19, Issue 3, p. 280-295. https://doi.org/10.1108/YC-08-2017-00722

Nefat, A. (2015) Zeleni marketing, Sveučilište Jurja Dobrile u Puli, Pula

Ottman, J. A. (2011) The new rules of green marketing. Strategies, tolls and inspiration for sustainable branding, Greenleaf Publishing Limited, Sheffield, UK. 2011.

Steinmetz, H., Knappstein, M., Ajzen, I., Schmidt, P., Kabst, R. (2016) How Effective are Behavior Change Interventions Based on the Theory of Planned Behavior? A Three-Level Metaanalysis, Zeitschrift für Psychologie, Vol. 224, Issue 3, p. 216-233. https://doi.org/10.1027/2151-2604/a000255

Terlau, W. i Hirsch, D. (2015) Sustainable Consumption and the Attitude-Behaviour-Gap Phenomenon - Causes and Measurements towards a Sustainable Development, International Journal Food System Dynamics, Vol. 6, Issue 3, p. $159-174$

TerraChoice Environmental Marketing Inc. (2007) The 'Six Sins of GreenwashingTM', A Study of Environmental Claims in North American Consumer Markets, www.sinsofgreenwashing.com, 26. 8. 2018.

Tolušić, Z., Dumančić, E., Bogdan, K. (2014) Društveno odgovorno poslovanje izeleni marketing, Agroeconomia Croatica, Vol. 4, Issue 1, p. 25-31

Tomić, M., Matić, K., Mesić, Ž., Cerjak, M. (2015) Čimbenici kupnje ekološkog kruha i pekarskih proizvoda, Agroeconomia Croatica, Vol. 5, Issue 1, p. 11-20

Uddin, M. F. i Khan, M. N. (2016) Exploring green purchasing behaviour of young urban consumers: Empirical evidences from India, South Asian Journal of Global Business Research, Vol. 5, Issue 1, p. 85-103. https://doi.org/10.1108/ SAJGBR-12-2014-0083

United States Census Bureau, https://www.census.gov/newsroom/press-releases/2015/cb15-113.html, 3. 11. 2018.

Wiernik, B. M., Ones, D. S., Dilchert, S. (2013) Age and environmental sustainability: a metaanalysis,Journal of Managerial Psychology, Vol. 28, Issue: 7/8, p. 826-856. https://doi.org/10.1108/JMP-07-2013-0221 


\title{
GREEN MARKETING ACCEPTANCE AMONG YOUNG CROATIAN CONSUMERS
}

\author{
Davor Širola \\ PhD, Senior Lecturer, Polytechnic of Rijeka, Vukovarska 58, 51000 Rijeka, Croatia; \\ e-mail:davor.sirola@veleri.hr
}

\section{Anabela Rosandić}

BSc; e-mail: anabelarosandic@gmail.com

\begin{abstract}
Recent global changes in our environment and society, implicate the need for more awareness about the importance of sustaining the environment, and consequently our own life quality. The increase of ecological consciousness leads towards the new segment of the so-called green consumers who prefer products and service without or with less negative effects on our living environment. The appearance of this group of consumers has enabled the development of a new marketing approach called the green marketing, lately known as the sustainable marketing as well. The green marketing favours production and consumption that consider their implication for the environment and society. The empirical research of this study is based on the application of a model of planned behaviour in order to establish the variables which are best predictors of intentions of young consumers (in the first place) regarding buying and using environmental friendly products and services. The results implicate that attitude of concern regarding our environment, knowledge about the environment and the awareness about the importance of preserving the environment are statistically significant predictors of buying intentions, while subjective norm has proven as a not statistically significant predictor. Additionally, the result shows that female respondents are more concerned about sustaining the environment, as well as the older age groups.
\end{abstract}

Key words: green marketing, environment, theory of planned behaviour 